ISSN 0258-7122 (Print), 2408-8293 (Online)

Bangladesh J. Agril. Res. 42(3): 393-401, September 2017

\title{
EFFECT OF HOT WATER TREATMENT IN CONTROLLING FUSARIUM WILT OF GLADIOLUS
}

\author{
L. YASMIN ${ }^{1}$, M. A. ALI' ${ }^{2}$ AND T. K. DEY ${ }^{3}$
}

\begin{abstract}
The experiment was conducted at the Horticulture Research Centre (HRC), Bangladesh Agricultural Research Institute (BARI), Gazipur during 2010-12 following two factors RCB design with four replications. The levels of Factor A (Duration): were i) $\mathrm{T}_{1}=5$ minutes, ii) $\mathrm{T}_{2}=10$ minutes and iii) $\mathrm{T}_{3}=15$ minutes Factor $\mathrm{B}$ (Water temperature): i) $\mathrm{A}_{1}=50^{\circ} \mathrm{C}$, ii) $\mathrm{A}_{2}=52^{\circ} \mathrm{C}$, iii) $\mathrm{A}_{3}=54^{\circ} \mathrm{C}$, iv) $\mathrm{A}_{4}$ $=56^{\circ} \mathrm{C}$ and $\mathrm{v}$ ) $\mathrm{A}_{5}=\mathrm{Control}$ (normal water). The treatment combinations were evaluated against the wilt disease of gladiolus (Fusarium oxysporum f. sp. gladioli) under naturally infested field condition. Corm treated with hot water at $54^{\circ} \mathrm{C}$ for 5 minutes was very effective in inhibiting the wilt disease incidence and thereby resulting better corm emergence, flower sticks plot ${ }^{-1}$, corm plot $^{-1}$ and comel yield of gladiolus. Corm treated with hot water at $52^{\circ} \mathrm{C}$ for 10 minutes appeared moderately effective against Fusarium wilt as well as better flower, corm and cormel yield of gladiolus under field condition.
\end{abstract}

Keywords: Gladiolus, Hot water, Fusarium oxysporum, Fusarium wilt.

\section{Introduction}

Gladiolus (Gladiolus $s p$ ) is one of the most popular commercial flower in Bangladesh. It is mainly cultivated for cut-flowers because of its elegant appearance and prolonged vase-life. Gladiolus spikes are most popular in flower arrangements and for preparing attractive bouquets. Its magnificent inflorescence with various colour have made it attractive for use in herbaceous border, bedding, rockeries, pots and for cut-flowers.

The agro-ecological conditions of the country are very conducive for the survival and culture of gladiolus. But there is no authentic report on the statistics of area under cultivation of this crop. The major production belts of this flower are Jessore sadar, Sharsha, Jhikargacha, Kushtia, Chuadanga, Satkhira, Khulna, Chittagong, Mymensingh, Dhaka, Savar and Gazipur. It has great economic value as a cut-flower and its cultivation is relatively easy. Income from gladiolus flower production is six times higher than from that of rice (Momin, 2006).

The major obstacle for cultivation of gladiolus in Subtropical and Mediterranean regions is the various diseases caused by fungi, bacteria and viruses of which Fusarium wilt disease caused by $F$. oxysporum f. sp. gladioli is a major problem

${ }^{1}$ Senior Scientific Officer, Horticulture Research Centre, Bangladesh Agricultural Research Institute (BARI), Joydebpur, Gazipur 1701, ${ }^{2}$ Professor, Department of Plant Pathology, Bangladesh Agricultural University (BAU), Mymensingh, ${ }^{3}$ Director, Pulse Research Centre, BARI, Ishurdi, Pabna, Bangladesh. 
in all over the gladiolus growing areas (Kulkurni, 2006). Fusarium wilt of gladiolus is considered as a serious and highly devastating disease which can cause $60-70 \%$ yield loss (Vlasova and Shitan, 1974), the damage may reach upto $100 \%$ (Pathania and Misra, 2000). Crop loss of 30\% in Germany and 60-80\% in Russia was estimated due to Fusarium wilt of gladiolus (Bruhn, 1955). It is also a serious problem in India. Fungal infection reduced plant growth and flowering with 15- 28\% decrease in the number of florets/spike (Misra et al., 2003). The incidence and severity of the disease vary from locality to locality. Kulkarni (2006) showed that the maximum incidence of leaf blight and corm rot of gladiolus was noticed in Dharwad district $(42.81 \%)$ followed by the Belgaum district $(27.46 \%)$ and least in Bangalore district (22.41\%) of India.

The pathogen is both seed and soil borne (Cohen and Hass, 1990; Mukhopadhyay, 1995). It causes curving, blending, arching, stunting, yellowing and drying of leaves associated with root and corm rot in the field as well as in the storage. F. oxysporum f. sp. gladioli causes three types of rot e.g. vascular corm rot, brown rot and basal rot (Partridge, 2003). Vascular rot is also called yellows and is characterized by a brown discoloration in the centre of the corm and extending into the flesh.The leaf symptoms start at the tip of the leaf blade and gradually spread all over the leaf blade. If the plant infected at later stage, it produces weak or small florets. When the plant is infected at early stage and infection is severe, whole plant becomes dry and dies within few days (Misra and Singh, 1998).

The most common method of controlling Fusarium and other fungal diseases infecting gladiolus corms was hot water treatment of the cormels before planting (Vigodsky, 1967; Hsieh, 1985). Cohen and Haas (1990) found that hot-water was effective for dormancy breaking of gladiolus cormels and also for disease management. They found that hot water treatment at $57^{\circ} \mathrm{C}$ for 30 minutes eradicated Fusarium as well as other pathogens. Others also found that hot water treatment of cormels eliminated the Fusarium wilt pathogen (Anon. 2009). Considering the above situation the present investigation was undertaken to study the effect of hot water treatment to control Fusarium wilt of gladiolus.

\section{Materials and Method}

The experiment was conducted at the Floriculture Field of Horticulture Research Centre (HRC) of Bangladesh Agricultural Research Institute (BARI), Gazipur during the period from 2010 to 2012. The experiment was laid out in randomized complete block design with four replications using two factors as Factor A (Duration): i) $\mathrm{T}_{1}=5$ minutes, ii) $\mathrm{T}_{2}=10$ minutes and iii) $\mathrm{T}_{3}=15$ minutes and Factor $\mathrm{B}$ (Water temperature): i) $\mathrm{A}_{1}=50^{\circ} \mathrm{C}$, ii) $\mathrm{A}_{2}=52^{\circ} \mathrm{C}$, iii) $\mathrm{A}_{3}=54^{\circ} \mathrm{C}$, iv) $\mathrm{A}_{4}$ $=56^{\circ} \mathrm{C}$ and v) $\mathrm{A}_{5}=$ Control (normal water). Corms were treated with hot water at $50^{\circ} \mathrm{C}, 52^{\circ} \mathrm{C}, 54^{\circ} \mathrm{C}$ and $56^{\circ} \mathrm{C}$ for 5,10 and 15 minutes of each treatment. For control treatment, the corms were soaked in normal water at room temperature for the same time. The corms were dried in shade before planting in the field. 
The experiment was conducted in previously Fusarium oxysporum infested soil. The recommended dose of fertilizers i.e. cowdung @ 10t/ha, TSP @ 225kg/ha, MoP $190 \mathrm{~kg} / \mathrm{ha}$ were applied to the soil during land preparation and thoroughly mixed with the soil before leveling. Urea @ 200kg/ha was top dressed in two equal splits, one at the four leaf stage and another at spike initiation stage (Woltz, 1976).

The treatments were randomly assigned in each block where unit plot size was $1.25 \mathrm{~m} \times 1.6 \mathrm{~m}$. Spacing was maintained at $25 \mathrm{~cm}$ between the rows and $20 \mathrm{~cm}$ between the plants. Depth of planting of the corms was $6 \mathrm{~cm}$. Two adjacent unit plots were separated by $50 \mathrm{~cm}$ space, and there was $75 \mathrm{~cm}$ space between the blocks. Data were recorded on Emergence, Days to 50\% emergence, Plant height , Pre emergence corm rot, Disease incidence, Percent disease index (PDI), Wilted plant, Days to $50 \%$ spike initiation, Spike length, Rachis length, Florets spike ${ }^{-1}$, Flower sticks plot ${ }^{-1}$, Flower sticks ha ${ }^{-1}$, Corms hill ${ }^{-1}$, Corm yield, Cormels hill-1 and Cormels yield. Assesment of disease incidence, disease index and wilted plant were calculated using following formula (Singh and Arora, 1994):

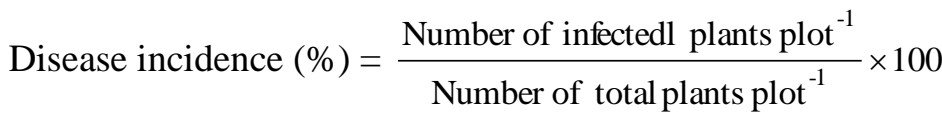

Percent disease index $(\%)=\frac{\text { Class frequency }}{\text { Total number of sample } \mathrm{x} \text { Maximum grade of scale }} \times 100$

Wilted plant $(\%)=\frac{\text { Number of dead plants plot }}{-1}=100$

The effect of different duration and temperature of gladiolus corms played remarkable role on emergence percentage and days to $50 \%$ emergence (Table 1). The maximum emergence (99\%) was recorded in corm treated at $54^{\circ} \mathrm{C}$ for 5 minutes and minimum emergence $(92 \%)$ was observed in normal water. Corm emergence was almost similar in other treatments. The minimum days (13) required to reach 50\% corm emergence was in case of 5 minutes treatment at $54^{\circ} \mathrm{C}$ and maximum days (35) required for $50 \%$ emergence was in 15 minutes treatment at $56^{\circ} \mathrm{C}$ (Table 1). No significant effect was observed in plant height due to hot water treatment.

The interaction effect with various duration and temperature of hot water treatment showed significant influence on Fusarium wilt disease of gladiolus (Table 2).

The pre - emergence corm rot, wilted plant and severity of Fusarium wilt of gladiolus was low in $54^{\circ} \mathrm{C}$ for 5 minutes while other treatments were almost statistically similar. The highest wilted plant (19.99\%) was recorded in $56^{\circ} \mathrm{C}$ for 15 minutes. The range of wilted plant was $3.94 \%$ to $10.15 \%$ in other combinations. Disease severity varied from 22.50 to $29.17 \%$ among the treatments. 
Table 1. Interaction effect of hot water treatment (duration and temperature) on emergence and vegetative growth of gladiolus

\begin{tabular}{|c|c|c|c|c|}
\hline \multicolumn{2}{|c|}{ Treatments } & \multirow{2}{*}{ Emergence (\%) } & \multirow{2}{*}{$\begin{array}{c}\text { Days to } 50 \% \\
\text { emergence }\end{array}$} & \multirow{2}{*}{$\begin{array}{l}\text { Plant height } \\
(\mathrm{cm})\end{array}$} \\
\hline Duration (min.) & Temperature $\left({ }^{0} \mathrm{C}\right)$ & & & \\
\hline \multirow[t]{5}{*}{5 minutes } & 50 & $93 \mathrm{~cd}$ & $14 \mathrm{~cd}$ & 36.50 \\
\hline & 52 & $97 \mathrm{~b}$ & $14 \mathrm{~cd}$ & 37.84 \\
\hline & 54 & 99 a & $13 \mathrm{~d}$ & 37.95 \\
\hline & 56 & $97 \mathrm{~b}$ & $14 \mathrm{~cd}$ & 37.77 \\
\hline & Normal water & $93 \mathrm{~cd}$ & $15 \mathrm{~cd}$ & 37.62 \\
\hline \multirow[t]{5}{*}{10 minutes } & 50 & $93 \mathrm{~cd}$ & $14 \mathrm{~cd}$ & 37.67 \\
\hline & 52 & $97 \mathrm{~b}$ & $15 \mathrm{~cd}$ & 37.81 \\
\hline & 54 & $97 \mathrm{~b}$ & $14 \mathrm{~cd}$ & 37.55 \\
\hline & 56 & $94 \mathrm{c}$ & $21 \mathrm{~b}$ & 36.78 \\
\hline & Normal water & $92 \mathrm{~d}$ & $15 \mathrm{~cd}$ & 36.41 \\
\hline \multirow[t]{5}{*}{15 minutes } & 50 & $94 \mathrm{c}$ & $16 \mathrm{c}$ & 37.67 \\
\hline & 52 & $97 \mathrm{~b}$ & $20 \mathrm{~b}$ & 36.67 \\
\hline & 54 & $94 \mathrm{c}$ & $20 \mathrm{~b}$ & 36.51 \\
\hline & 56 & $92 \mathrm{~d}$ & $35 \mathrm{a}$ & 34.50 \\
\hline & Normal water & $92 \mathrm{~d}$ & $15 \mathrm{~cd}$ & 37.32 \\
\hline $\mathrm{CV} \%$ & & 0.71 & 7.38 & 9.31 \\
\hline
\end{tabular}

Means followed by the same letters in a column did not differ significantly at the 5\% level of probability.

Table 2. Interaction effect of duration and temperature of hot water on disease infection of gladiolus

\begin{tabular}{|c|c|c|c|c|}
\hline \multicolumn{2}{|c|}{ Treatments } & \multirow{2}{*}{$\begin{array}{l}\text { Pre-emergence } \\
\text { corm rot }(\%)\end{array}$} & \multirow{2}{*}{$\begin{array}{l}\text { Wilted plant } \\
\qquad(\%)\end{array}$} & \multirow{2}{*}{$\begin{array}{l}\text { Disease severity } \\
\text { (PDI) }\end{array}$} \\
\hline Duration (min.) & Temperature $\left({ }^{0} \mathrm{C}\right)$ & & & \\
\hline \multirow[t]{5}{*}{5} & 50 & $7.17 \mathrm{a}(2.67)$ & $6.76 \mathrm{~cd}(2.59)$ & $29.17 \mathrm{a}(31.50)$ \\
\hline & 52 & 3.83 b (1.94) & 3.94 e (1.96) & $25.00 \mathrm{bcd}(28.87)$ \\
\hline & 54 & 1.33 c (1.05) & 3.85 e (1.94) & $22.50 \mathrm{~d}(27.23)$ \\
\hline & 56 & 3.83 b (1.94) & $6.53 \mathrm{~cd}(2.54)$ & $24.17 \mathrm{~cd}(28.36)$ \\
\hline & Normal water & $7.17 \mathrm{a}(2.67)$ & $9.25 \mathrm{bc}(3.03)$ & $29.17 \mathrm{a}(31.50)$ \\
\hline \multirow[t]{5}{*}{10} & 50 & $7.17 \mathrm{a}(2.67)$ & $4.96 \mathrm{de}(2.21)$ & 25.00 bcd (28.87) \\
\hline & 52 & 3.83 b (1.94) & 3.94 e (1.96) & $22.50 \mathrm{~d}(27.23)$ \\
\hline & 54 & 3.83 b (1.94) & $4.82 \mathrm{de}(2.17)$ & $25.00 \mathrm{bcd}(28.87)$ \\
\hline & 56 & $6.33 \mathrm{a}(2.51)$ & $6.69 \mathrm{~cd}(2.58)$ & 26.67 abc (29.99) \\
\hline & Normal water & $8.67 \mathrm{a}(2.94)$ & $10.15 \mathrm{~b}(3.18)$ & $29.17 \mathrm{a}(31.50)$ \\
\hline \multirow[t]{5}{*}{15} & 50 & $6.33 \mathrm{a}(2.51)$ & $4.91 \mathrm{de}(2.20)$ & $25.00 \mathrm{bcd}(28.87)$ \\
\hline & 52 & 3.83 b (1.94) & $4.82 \mathrm{de}(2.17)$ & $24.17 \mathrm{~cd}(28.36)$ \\
\hline & 54 & $6.33 \mathrm{a}(2.51)$ & $6.69 \mathrm{~cd}(2.58)$ & $25.00 \mathrm{bcd}(28.87)$ \\
\hline & 56 & 8.67 a (2.94) & 19.99 a (4.47) & $27.50 \mathrm{ab}(30.51)$ \\
\hline & Normal water & 8.67 a (2.94) & $10.15 \mathrm{~b}(3.18)$ & $29.17 \mathrm{a}(31.50)$ \\
\hline $\mathrm{CV} \%$ & & 13.18 & 11.61 & 3.38 \\
\hline
\end{tabular}

Means followed by the same letters in a column did not differ significantly at the $5 \%$ level of probability. 
A negative correlation between production of flower sticks ha ${ }^{-1}$ and percentage of plant infection was found to be highly significant $(r=-0.819)$ (Fig. 1). The negative relationship indicated that flower sticks ha-1 decreased with the increasing of plant infection (\%). The equation $(y=-723.38 x+124007)$ stated that flower sticks $\mathrm{ha}^{-1}$ decreases at the rate of 723.38 flower sticks ha- ${ }^{-1}$ per unit change of plant infection. The $\mathrm{R}^{2}$ value indicated that $67.1 \%$ reduction of flower sticks ha ${ }^{-1}$ was attributed due to plant infection.

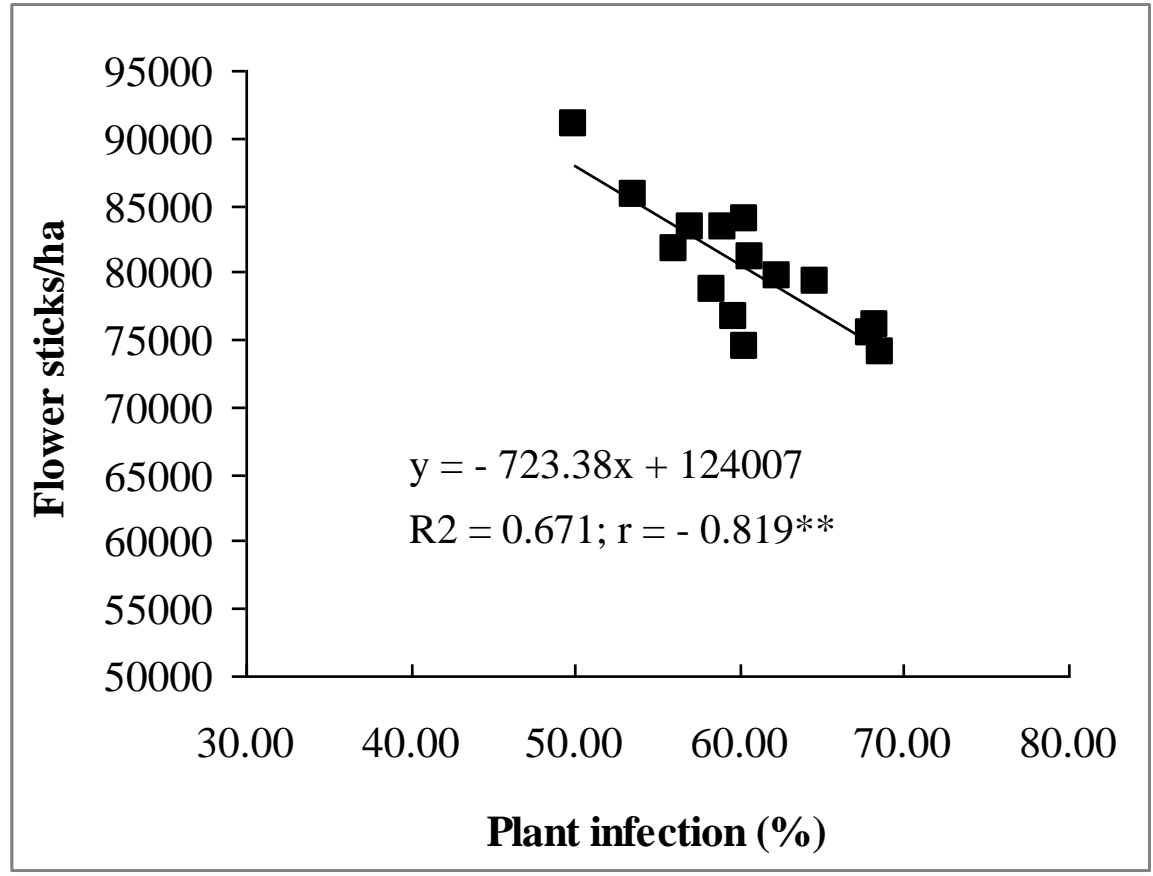

Fig. 1. Relationship between flower sticks ha' ${ }^{-1}$ and plant infection (\%)

There was significant effect of hot water treatment with various duration and temperature on days to $50 \%$ spike initiation and characteristics of gladiolus flower (Table 3). Five minutes treatment at $54^{\circ} \mathrm{C}$ or $56^{\circ} \mathrm{C}$ required 85 days for $50 \%$ spike initiation. The maximum days (97-98) required in other treatments. The highest number of flower sticks $\left(38.33\right.$ plot $\left.^{-1}\right)$ was obtained from 5 minutes treatment at $54^{0} \mathrm{C}$ and the lowest sticks $\left(31\right.$ plot $\left.^{-1}\right)$ in normal water. Other characters of gladiolus flower did not differ significantly by hot water treatment.

The interaction effect of hot water treatments with various duration and temperature had significant influence on corms plot $^{-1}$ and ha $^{-1}$ but not other characters of corm (Table 4). The number of corms was 54.90 plot $^{-1}$ and 131.00 $\mathrm{ha}^{-1}$ in case of 5 minutes treatment at $54^{\circ} \mathrm{C}$ and minimum number of corms plot $^{-1}$ and ha ${ }^{-1}$ were recorded in 15 minutes treatment at $56^{\circ} \mathrm{C}$. 
Table 3. Interaction effect of duration and temperature of hot water on flower production of gladiolus

\begin{tabular}{|c|c|c|c|c|c|}
\hline \multicolumn{2}{|c|}{ Treatments } & \multirow{2}{*}{$\begin{array}{c}\text { Days to } 50 \% \\
\text { spike initiation }\end{array}$} & \multirow{2}{*}{$\begin{array}{l}\text { Spike } \\
\text { length } \\
(\mathrm{cm})\end{array}$} & \multirow{2}{*}{$\begin{array}{l}\text { Rachis } \\
\text { length } \\
(\mathrm{cm})\end{array}$} & \multirow{2}{*}{$\begin{array}{c}\text { Flower } \\
\text { sticks plot }{ }^{-1}\end{array}$} \\
\hline $\begin{array}{l}\text { Duration } \\
\text { (min.) }\end{array}$ & $\begin{array}{l}\text { Temperature } \\
\left({ }^{0} \mathrm{C}\right)\end{array}$ & & & & \\
\hline \multirow{5}{*}{5} & 50 & $86 \mathrm{~b}$ & 67 & 40 & 33.33 bcde \\
\hline & 52 & $86 \mathrm{~b}$ & 66 & 42 & $35.33 \mathrm{abc}$ \\
\hline & 54 & $85 \mathrm{~b}$ & 70 & 43 & $38.33 \mathrm{a}$ \\
\hline & 56 & $85 \mathrm{~b}$ & 66 & 42 & 35 abcd \\
\hline & Normal water & $87 \mathrm{~b}$ & 65 & 38 & 32 cde \\
\hline \multirow{5}{*}{10} & 50 & $86 \mathrm{~b}$ & 65 & 41 & 33.33 bcde \\
\hline & 52 & $85 \mathrm{~b}$ & 68 & 43 & $36 \mathrm{ab}$ \\
\hline & 54 & $86 \mathrm{~b}$ & 65 & 42 & $35 \mathrm{abcd}$ \\
\hline & 56 & $97 \mathrm{a}$ & 68 & 42 & 32.33 cde \\
\hline & Normal water & $86 \mathrm{~b}$ & 66 & 39 & $31.67 \mathrm{de}$ \\
\hline \multirow{5}{*}{15} & 50 & $87 \mathrm{~b}$ & 65 & 41 & 34 bcde \\
\hline & 52 & $97 \mathrm{a}$ & 66 & 41 & 34.33 bcde \\
\hline & 54 & $97 \mathrm{a}$ & 67 & 40 & 33 bcde \\
\hline & 56 & $98 \mathrm{a}$ & 67 & 40 & $31.3 \mathrm{e}$ \\
\hline & Normal water & $87 \mathrm{~b}$ & 65 & 38 & $31 \mathrm{e}$ \\
\hline CV\% & & 1.61 & 7.28 & 10.79 & 6.49 \\
\hline
\end{tabular}

Means followed by the same letters in a column did not differ significantly at the $5 \%$ level of probability.

Table 4. Interaction effect of duration and temperature on corm production of gladiolus

\begin{tabular}{|c|c|c|c|c|c|}
\hline \multicolumn{2}{|c|}{ Treatments } & \multirow{2}{*}{$\begin{array}{l}\text { Corms } \\
\text { hill }^{-1}\end{array}$} & \multirow[b]{2}{*}{$\begin{array}{c}\text { Corm } \\
\text { weight (g) }\end{array}$} & \multirow[b]{2}{*}{$\begin{array}{l}\text { Corms } \\
\text { plot }^{-1}\end{array}$} & \multirow[b]{2}{*}{$\begin{array}{c}\text { Corms } \\
\text { ha-1 }^{-1}(000)\end{array}$} \\
\hline $\begin{array}{c}\text { Duration } \\
\text { (min.) }\end{array}$ & $\begin{array}{c}\text { Temperature } \\
\left({ }^{\circ} \mathrm{C}\right)\end{array}$ & & & & \\
\hline \multirow{5}{*}{5} & 50 & 1.33 & 17.10 & $46.60 \mathrm{cde}$ & $110.67 \mathrm{~cd}$ \\
\hline & 52 & 1.37 & 17.62 & $50.97 \mathrm{abc}$ & $121.33 \mathrm{abc}$ \\
\hline & 54 & 1.43 & 18.83 & $54.90 \mathrm{a}$ & $131.00 \mathrm{a}$ \\
\hline & 56 & 1.37 & 17.48 & $49.60 \mathrm{abcd}$ & $118.33 \mathrm{abc}$ \\
\hline & Normal water & 1.30 & 16.50 & $44.20 \mathrm{def}$ & $105.00 \mathrm{de}$ \\
\hline \multirow{5}{*}{10} & 50 & 1.37 & 16.82 & 48.70 bcde & $116.00 \mathrm{bcd}$ \\
\hline & 52 & 1.40 & 18.20 & $52.27 \mathrm{ab}$ & $124.67 \mathrm{ab}$ \\
\hline & 54 & 1.40 & 17.27 & $51.73 \mathrm{abc}$ & $123.33 a b c$ \\
\hline & 56 & 1.33 & 17.43 & $47.10 \mathrm{bcde}$ & $112.00 \mathrm{bcd}$ \\
\hline & Normal water & 1.33 & 16.83 & 44.00 ef & $104.67 \mathrm{de}$ \\
\hline \multirow{5}{*}{15} & 50 & 1.37 & 17.43 & 49.20 bcde & $117.33 \mathrm{bcd}$ \\
\hline & 52 & 1.37 & 17.00 & $50.47 \mathrm{abc}$ & $120.33 a b c$ \\
\hline & 54 & 1.33 & 16.89 & 47.07 bcde & $112.00 \mathrm{bcd}$ \\
\hline & 56 & 1.33 & 16.88 & $39.07 \mathrm{f}$ & $93.33 \mathrm{e}$ \\
\hline & Normal water & 1.33 & 16.00 & $44.00 \mathrm{ef}$ & $104.67 \mathrm{de}$ \\
\hline CV\% & & 4.56 & 9.11 & 6.86 & 6.82 \\
\hline
\end{tabular}

Means followed by the same letters in a column did not differ significantly at the $5 \%$ level of probability. 
The effect of hot water treatment with different duration and temperature showed significant differences on cormel production (Table 5). The highest cormel weight hill ${ }^{-1}(28.67 \mathrm{~g})$ was recorded in $54^{\circ} \mathrm{C}$ for 5 minutes and the lowest $(19.67 \mathrm{~g})$ was recorded in $56^{\circ} \mathrm{C}$ for 15 minutes. The range of cormel weight was $22.17 \mathrm{~g}$ to $27.33 \mathrm{~g} \mathrm{hill}{ }^{-1}$ in other treatments. The maximum cormel yield was $1097.0 \mathrm{~g} \mathrm{plot}^{-1}$ and $2.61 \mathrm{tha}^{-1}$ in case of $54^{\circ} \mathrm{C}$ temperature for 5 minutes. The lowest cormel yield was $576.0 \mathrm{~g} \mathrm{plot}^{-1}$ and $1.37 \mathrm{t} \mathrm{ha-}{ }^{1}$ recorded in $56^{\circ} \mathrm{C}$ temperature for 15 minutes. The range of the cormel yield in other treatments was $754.0 \mathrm{~g}$ to $1021.0 \mathrm{~g} \mathrm{plot}^{-1}$ and $1.79 \mathrm{t}$ to $2.43 \mathrm{t} \mathrm{ha}{ }^{-1}$.

Table 5. Interaction effect of duration and temperature on cormel production of gladiolus

\begin{tabular}{|c|c|c|c|c|c|}
\hline \multicolumn{2}{|c|}{ Treatments } & \multirow{2}{*}{$\begin{array}{l}\text { Cormels } \\
\text { hill }^{-1}\end{array}$} & \multirow{2}{*}{$\begin{array}{l}\text { Cormel weight } \\
\text { hill-1 }^{-1}(\mathrm{~g})\end{array}$} & \multirow{2}{*}{$\begin{array}{l}\text { Cormel yield } \\
\text { plot }^{-1}(\mathrm{~g})\end{array}$} & \multirow{2}{*}{$\begin{array}{c}\text { Cormel yielc } \\
\text { ha }^{-1}(\mathrm{t})\end{array}$} \\
\hline $\begin{array}{l}\text { Duration } \\
\text { (min.) }\end{array}$ & $\begin{array}{c}\text { Temperature } \\
\left({ }^{\circ} \mathrm{C}\right)\end{array}$ & & & & \\
\hline \multirow{5}{*}{5} & 50 & 17.67 & $25.17 \mathrm{de}$ & $878.0 \mathrm{c}$ & $2.09 \mathrm{c}$ \\
\hline & 52 & 19.67 & $26.83 \mathrm{bc}$ & $1001.0 \mathrm{~b}$ & $2.38 \mathrm{~b}$ \\
\hline & 54 & 20.00 & $28.67 \mathrm{a}$ & $1097.0 \mathrm{a}$ & $2.61 \mathrm{a}$ \\
\hline & 56 & 19.67 & $27.00 \mathrm{~b}$ & $979.0 \mathrm{~b}$ & $2.33 \mathrm{~b}$ \\
\hline & Normal water & 16.33 & $23.00 \mathrm{~g}$ & $782.0 \mathrm{~d}$ & $1.86 \mathrm{~d}$ \\
\hline \multirow{5}{*}{10} & 50 & 18.67 & $25.50 \mathrm{de}$ & $909.0 \mathrm{c}$ & $2.16 \mathrm{c}$ \\
\hline & 52 & 19.33 & $27.33 \mathrm{~b}$ & $1021.0 \mathrm{~b}$ & $2.43 \mathrm{~b}$ \\
\hline & 54 & 18.00 & $24.33 \mathrm{ef}$ & $903.0 \mathrm{c}$ & $2.15 \mathrm{c}$ \\
\hline & 56 & 14.67 & $22.17 \mathrm{~g}$ & $784.0 \mathrm{~d}$ & $1.87 \mathrm{~d}$ \\
\hline & Normal water & 17.33 & $23.33 \mathrm{fg}$ & $770.0 \mathrm{~d}$ & $1.83 \mathrm{~d}$ \\
\hline \multirow{5}{*}{15} & 50 & 18.00 & $25.67 \mathrm{~cd}$ & $924.0 \mathrm{c}$ & $2.20 \mathrm{c}$ \\
\hline & 52 & 18.33 & 24.33 ef & $901.0 \mathrm{c}$ & $2.14 \mathrm{c}$ \\
\hline & 54 & 16.00 & $22.67 \mathrm{~g}$ & $800.0 \mathrm{~d}$ & $1.90 \mathrm{~d}$ \\
\hline & 56 & 14.00 & $19.67 \mathrm{~h}$ & $576.0 \mathrm{e}$ & $1.37 \mathrm{c}$ \\
\hline & Normal water & 16.67 & $22.83 \mathrm{~g}$ & $754.0 \mathrm{~d}$ & $1.79 \mathrm{~d}$ \\
\hline CV\% & & 10.10 & 2.97 & 3.27 & 3.27 \\
\hline
\end{tabular}

Means followed by the same letters in a column did not differ significantly at the 5\% level of probability.

Study on the effect of hot water treatment in controlling Fusarium wilt of gladiolus revealed that corm treatment by hot water was effective. Among the different temperature and duration of hot water treatment, corm treated by hot water at $54^{\circ} \mathrm{C}$ for 5 minutes was very effective in inhibiting the wilt disease incidence and thereby resulting increased corm emergence (\%), flower sticks plot $^{-1}$, corm plot $^{-1}$ and comel yield of gladiolus under field condition. An investigation was carried out by Cohen and Hass (1990) and found that hot water 
had positive effect in disease management and dormancy breaking of gladiolus cormels. They found that hot water treatment of $57^{\circ} \mathrm{C}$ for 30 minutes eradicated Fusarium as well as other pathogens. In an experiment in university of California found it was that hot water treatment of cormels eliminated the Fusarium yellows (Anon., 2009). From the present investigation, corm treated by hot water at $52^{\circ} \mathrm{C}$ for 10 minutes was moderately effective against Fusarium wilt. Corm treated by hot water at $56^{\circ} \mathrm{C}$ for 15 minutes showed maximum plant mortality. In contrast Roistacher et al. (1957) reported that this fungus died between 53.3 and $56.7^{\circ} \mathrm{C}$ whereas cormels died above $56.7^{\circ} \mathrm{C}$.

\section{Conclusion}

Corm treated with hot water at $54^{\circ} \mathrm{C}$ for 5 minutes was very effective in inhibiting the disease infestation as well as gave the increased corm emergence $(\%)$, flower sticks plot ${ }^{-1}$, corm plot ${ }^{-1}$ and comel yield of gladiolus. Besides, corm treated with hot water at $52^{\circ} \mathrm{C}$ for 10 minutes appeared moderately effective against Fusarium wilt as well as better flower, corm and cormel yield of gladiolus.

\section{References}

Anonymous. 2009. UC IPM Online Statewide Integrated Pest Managment Program. Uni. California. http://www. ipm. ucdavis. edu/PMG/r280111611.html.

Bruhn. 1955. Untersuchungen uber die Fusarium krankheit de gladiolen. Phytopathology, 25: $1-38$.

Cohen, A. and H.V. Hass. 1990. Hot water treatment tolerance in gladiolus cormels and their state of dormancy. Agril. Res. Org., The Volcani Centre, Israel. 495- 503.

Hsieh, S.P.Y. 1985. Ecology and control of gladiolus Fusarium wilt. Plant Prot. Bull. Taiwan. 27: 247- 256.

Kulkurni S.P. 2006. Studies on Fusarium oxysporum Schlecht Fr f. sp. gladioli (Massey) snyd. \& Hans. causing wilt of gladiolus. M. Sc. (Agri.) Thesis, Dept. Plant Pathology, University of Agricultural Sciences, Dharwad, 89p.

Misra, R.L. and B. Sngh. 1998: Gladiolus. In: Commercial Flowers. (Eds) Bose, T. K. and L. P. Yadav. Naya Prokash, Calcutta, India. Pp. 266-353.

Misra, R.L., B. Sing and S.K. Palai. 2003. Galdiolus. In. Commercial Flowers. Vol-2. $2^{\text {nd }}$ Rev. ed. Nayaprokash. Calcutta, India. Pp. 1-113.

Momin, M.A. 2006. Floriculture Survey in Bangladesh. A Consultancy Report. FAO/ UNDP (IHNDP/BGD/97/06).

Mukhopadhyay, A.N. 1995: Exploitation of Gliocladium virens and Trichoderma harzianum for biological seed treatment against seed borne disease. Indian J. Mycol. Plant Pathol. 2(1\&2): 124.

Pathania, N.S. and R.I. Misra. 2000. In vitro mutagenesis studies in gladiolus for induction of resistance to Fusarium oxysporum f. sp. gladioli. International Horticultural Congress: Elegant Science in Floriculture. Acta Horticulturae 624, 26. 
Partridge, J.E. 2003. Fusarium rot and yellows of gladiolus. Department of Plant Pathology, University of Nebraska, Lincoln, NE, USA, 47 p.

Roistacher, C.N., K.F. Baker and J.G. Bald. 1957. Hilgardia, 26: 659- 84.

Singh, P.J. and J.S. Arora. 1994. Chemical control of Fusarium yellows and corm rot (Fusarium oxysporum f. sp. gladioli) of gladiolus. Oxford and IBH publishing Co. Pvt. Ltd. Calcutta. Pp. 461- 462.

Vigodsky, H. 1967. Hot water treatment as a method for control of Fusarium disease in gladiolus and Iris. Ist. Israel Congr. Plant Path. (Summarise of Lectures) Pp.60-62.

Vlasova, V. J. and N. Shitan. 1974: Means of increasing resistance of plant to Fusarium wilt NAUCHN TRUDY STRAVROOL SK 37: 127-133.

Woltz, S.S. 1976. Fertilization of gladiolus. Gladio Grams, NAGC, No. 21: 1-5. 
